P-ISSN: 2615-1723

E-ISSN: 2615-1766

April 2018
Jurnal Riset Pendidikan Dasar

1 (1), (2018) 49-55

Submitted: Februari, Accepted: Maret, Published: April

\title{
APLIKASI ASESMEN DALAM PEMBELAJARAN IPA DI KELAS IV SEKOLAH DASAR NEGERI GELOGOR
}

\author{
Mansur S \\ Prodi Pendidikan Biologi, FKIP Universitas Nusa Nipa, Indonesia \\ E-mail: mansursaputra00@gmail.com
}

\begin{abstract}
Abstrak
Penelitian kualitatif ini menggunakan rancangan penelitian tindakan kelas. Subjek penelitiannya kelas IV SD Negeri Gelogor. Penelitian ini bertujuan untuk mengetahui bagaimana guru mengaplikasikan asesmen dalam pembelajaran IPA di kelas IV SD Negeri Gelogor sebagai suatu upaya meningkatkan efektivitas pelaksanaan evaluasi di sekolah dasar. Untuk mencapai tujuan ini diperlukan data empirik yang diperoleh dari kelas yang diberi tindakan dengan menggunakan teknik observasi, wawancara, dan evaluasi. Analisis data dilakukan selama dan sesudah pengumpulan data di lapangan. Pengamatan dilakukan secara ongoing proses, saat guru melakukan tindakan pembelajaran IPA. Hasil yang diperoleh adalah sebelum guru melaksanakan asesmen terlebih dahulu membuat rancangan alat evaluasi bersamaan dengan rancangan pembelajaran yang akan dilaksanakan. Kemudian saat pembelajaran berlangsung guru melaksanakan rancangan alat evaluasinya. Dalam pelaksanaan pembelajaran IPA tersebut guru berhasil melaksanakan asesmen dalam bentuk a) penilaian proses, b) portofolio, c) wawancara dan diskusi, dan d) tes formatif.
\end{abstract}

Kata kunci: Asesmen, Pembelajaran IPA.

\section{Assessment Application In Learning Natural Science Of Class IV Of Gelogor State Elementary School}

\begin{abstract}
This research is a classroom-based action research. The subjects of the research were the fourth grade students of SD Negeri Gelogor. The purpose of the study was to identifity how the teacher applied the assesment in natural sciences learning as as an attempt to increase the effectiveness of evaluation process in elementary school. The data were gathered by using observation, interviews and test. Data analysis was done during and after the collection of data in the field. The observation was done as an angoing process, that is while the teacher was teaching natural sciences. The results of the study were the teacher designed the evaluation instrument together with instructional plan before she did the assesment. As the teaching learning process was going on, the teacher applied the evaluation instrument which had been designed. In conducting the teaching and learning of natural sciencies the teacher was succesful in implementing the assesment in the forms of : a) procees evaluation, b) portfolio, c) enterview and discussion, and d) formative test.
\end{abstract}

Key Words: Assessment, Natural sciences study. 


\section{Jurnal Riset Pendidikan Dasar, 01 (1), April 2018 (49-55)}

Mansur S

\section{PENDAHULUAN}

Evaluasi merupakan bagian yang tak terpisahkan dari kegiatan belajar mengajar khususnya, dan dalam bidang pendidikan pada umumnya. Pendidikan merupakan proses untuk mengubah secara positif perilaku siswa yang belajar. Dengan demikian evaluasi berperan untuk memberikan informasi tentang ada tidaknya perubahan yang terjadi pada siswa dan seberapa besar perubahan itu.

Tugas profesional guru adalah mengusahakan terjadinya perkembangan belajar siswa baik perkembangan kognitif, motorik, maupun afektif. Untuk mengetahui perkembangan siswa, guru harus melaksanakan asesmen. Asesmen (Latief, 1997) adalah suatu kegiatan dalam proses belajar mengajar yang dirancang oleh guru untuk mengetahui perkembangan belajar siswa. Fungsi asesmen menurut Iskandar (1997:92) adalah: 1) sebagai alat untuk merencanakan, pedoman, dan memperkaya suatu pembelajaran di kelas; 2) sebagai alat komunikasi dengan murid-murid; 3) sebagai alat untuk memonitor hasil belajar dan perbaikan pembelajaran; 4) sebagai alat untuk memperbaiki kurikulum dan pengajaran.

Dalam buku "Pedoman Pelaksanaan Penilaian di Sekolah Dasar" (Depdik-bud, 1994), dikatakan bahwa jenis penilaian yang dilaksanakan di SD adalah: 1) ulangan harian; 2) pemberian tugas, dan 3) ulangan umum. Ketiga penilaian ini mengacu pada pelaksanakaan asesmen. Kenyataan yang terjadi di lapangan, tiga jenis penilaian di atas dijabarkan menjadi: 1) ulangan harian disebut sebagai (a) tes formatif, (b) pengamatan, 2) pemberian tugas yang menekankan pada pembebanan siswa mengerjakan pekerjaan rumah (PR), 3) ulangan umum. Dari wawancara yang telah dilakukan baik kepada guru-guru sekolah dasar maupun beberapa kepala sekolah dasar, diperoleh masukan bahwa mereka masih rancu dalam melaksanakan kegiatan jenis penilaian. Kerancuan yang terjadi itu adalah pada saat guru akan memberikan nilai "Pengamatan dan
Pemberian Tugas". Para guru sepakat mengatakan bahwa, kalau satu pelajaran mendapat nilai 9 , maka nilai pengamatannya akan 9 juga. Sedangkan nilai pekerjaan rumahnya, para guru akan mencari rata-rata dari sejumlah nilai yang diperoleh dari beberapa pekerjaan rumah yang dikerjakan siswa.

Penilaian yang dilaksanakan di Sekolah Dasar Negeri Gelogor, Desa Mas-mas, Kec. Batukliang Utara Lombok Tengah, Nusa Tenggara Barat. belum sesuai dengan pelaksanaan penilaian yang ada di buku Pedoman Pelaksanaan Penilaian di Sekolah Dasar atau asesmen. Usaha perbaikan penilaian tersebut akan dilakukan melalui penelitian tindakan kelas dengan judul "Aplikasi Asesmen dalam Pembelajaran IPA di kelas IV SD Negeri Gelogor, (sebagai suatu Upaya Meningkatkan Pelaksanaan Evaluasi di Sekolah Dasar)"

Asesmen adalah suatu kegiatan dalam proses belajar mengajar yang dirancang oleh guru untuk mengetahui perkembangan belajar siswa. Asesmen berbeda dengan pengukuran prestasi belajar (Iskandar, 1997:92). Pengukuran prestasi belajar menyangkut pengumpulan informasi tentang prestasi murid melalui tes dan lembar kerja, sedangkan asesmen merupakan konsep yang lebih luas yang mencakup penilaian profesional pendidik, perasaan dan pengamatan, serta informasi-informasi lain yang dikumpulkan dari lingkungan belajar.

Pelaksanaan asesmen dalam pembelajaran dapat dipilah menjadi 2 (dua) macam yaitu pada saat proses belajar dan hasil belajar (Rofi'uddin, 1999:124). Sasaran yang diasesmen saat proses belajar adalah tingkat efektivitas kegiatan belajar dalam rangka pencapaian tujuan pembelajaran. Sedangkan sasaran yang diasesmen pada akhir pembelajaran adalah tingkat penguasaan siswa terhadap apa yang telah dipelajarinya.

Sasaran yang dituju adalah mengusahakan terjadinya perkembangan kognitif (pengetahuan), motorik (ketrampilan), 


\section{Jurnal Riset Pendidikan Dasar, 01 (1), April 2018 (18-24) Mansur S}

maupun afektif (emosi, perilaku, rasa aman, kepedulian lingkungan, dan sebagainya). Untuk dapat melaksanakan asesmen tersebut guru harus dapat merancangnya sesuai dengan karakteristik materi pelajaran yang diberikan, apakah dalam bentuk: 1) tes tertulis atau tes pensil kertas, 2) lembar observasi atau kinerja murid, 3) mempergunakan tes gambar dengan sedikit keterangan, 4) mempergunakan jurnal, 5) mempergunakan peta konsep, dan 6) mempergunakan porto folio (Anthony, 1991).

\section{METODE}

Rancangan penelitian ini adalah rancangan penelitian tindakan kelas tentang pelaksanaan evaluasi pengajaran diangkat dari pembelajaran di kelas. Masalah tersebut diidentifikasi melalui (1) kajian awal, (2) pencarian fakta secara kolaboratif antara peneliti dengan guru, (3) penyusunan permasalahan umum tindakan, (4) perancangan umum tindakan dengan memberikan tindakan yang signifikan dengan masalah yang muncul di kelas. Tindakan yang diberikan itu adalah perancangan asesmen, pelaksanaan asesmen di SD Negeri Gelogor.

Proses pelaksanaan tindakan dilakukan dalam 4 (empat) tahap secara berdaur ulang yang berawal dari (1) perencanaan, (2) tindakan, (3) peng-amatan, dan (4) refleksi (Kurt Lewin, dalam Tantra, 1997:21). Siklus tindakan yang dilaksanakan dalam penelitian ini sebanyak 2 (dua) kali.

Data yang diperlukan untuk sampai pada tujuan penelitian ini adalah data tindakan (non verbal) dan data verbal. Data tindakan atau perilaku berupa aktivitas fisik guru dan murid selama pembelajaran berlangsung. Data verbal berupa hasil penilaian yang dilakukan oleh praktisi. Data penelitian diperoleh dari sumber data berupa aktivitas guru dalam melaksanakan asesmen di kelas IV SD Negeri Gelogor.

Sumber data primer (data tindakan) diambil dari data empiris (fakta) kegiatan guru dalam pembelajaran yang mengaplikasikan asesmen dalam pembelajaran IPA di kelas IV.
Data tersebut dikumpulkan dari pelaksanaan pembelajaran IPA di kelas IV semester genap tahun ajaran 2015/2016.

Instrumen pengumpulan data digunakan lembar observasi APKG yang dimodifikasi disesuaikan dengan kerangka teori yang digunakan untuk keperluan ini yaitu karakteristik interaksi belajar mengajar IPA yang mengaplikasikan asesmen dalam pembelajarannya. Instrumen pengumpulan data yang lain dipergunakan juga: (a) catatan lapangan, observasi dan perekaman, (b) wawancara dan (c) evaluasi.

Dalam penelitian ini data tentang pelaksanaan asesmen dalam pembela-jaran IPA di analisis dengan teknik data kualitatif model mengalir (Miles dan Huberman, 1992:18). Target analisis data adalah (1) level observasi, (2) level deskripsi, dan (3) level eksplanatori.

1) Level Observasi

Berdasarkan catatan yang terdapat dalam instrumen pengumpulan data, peneliti melakukan seleksi dan pengkodean. Melalui seleksi, peneliti melakukan kodifikasi terhadap data tindakan dan verbal dengan memisah-kan data yang tidak relevan.

Pelaksanaan asesmen dalam pembelajaran IPA di kelas IV dikatakan berhasil jika pelaksanaan pembelajaran itu minimal telah mencapai persentase $70 \%$ - $84 \%$ yang berarti "Baik" (IKIP, FIP, 1996:34) dari sejumlah deskriptor yang telah tersusun dalam lembar observasi dari aspek: "karakteristik interaksi belajar mengajar guru dan siswa dalam pembelajaran IPA". Jika dalam pelaksanaan pembelajaran, setelah praktisi mendapat pengajaran, ternyata masih ada butir-butir pelaksanaan pembelajaran yang masih belum tercapai, maka peneliti bersama praktisi mengadakan refleksi untuk merencanakan tindakan berikutnya. Tindakan ini dilaksanakan sampai waktu penelitian berakhir.

2) Level Deskripsi

Dengan memanfaatkan hasil refleksi dan kodifikasi, peneliti menata data dan satuan-

Copyright (C2018, JRPD, ISSN 2615 - 1723 (Print), ISSN 2615 - 1766 (Online) 


\section{Jurnal Riset Pendidikan Dasar, 01 (1), April 2018 (49-55) \\ Mansur S}

satuan peristiwa, satuan makna, pola atau kecenderungan. Deskripsi data disajikan dalam kalimat-kalimat sederhana lugas, efektif sehingga mudah dipahami.

3) Level Eksplanatori

Analisis ditekankan pada pemberian penjelasan (a) mengapa suatu tindakan dapat atau tidak mempengaruhi subjek terteliti atau situasi kelas pada umumnya, dan (b) bagaimana suatu aspek tindakan berpengaruh pada yang lain. Hasil analisis level ini bermanfaat untuk merefleksi tindakan selanjutnya. Keseluruhan hasil analisis selanjutnya disimpulkan. Penarikan kesimpulan dilaksanakan dengan lugas, tetapi terbuka (Miles dan Huberman, 1992).

\section{HASIL DAN PEMBAHASAN}

Kegiatan siklusif yang dilaksanakan dalam penelitian ini sebanyak 2 (dua) kali. Untuk memudahkan pemahaman terhadap proses tindakan yang dilak-sanakan dan hasil yang diperoleh setiap siklus, uraian berikut dibagi menjadi: (1) kegiatan siklusif, dan (2) hasil pelaksanaan tindakan.

Kegiatan Siklusif

1. Siklus 1

a) Perencanaan Siklus 1

Perencanaan tatap muka mengajar yang dibuat praktisi disajikan pada tabel 1 .

Tabel 1. Pelaksanaan Pembelajaran IPA

\begin{tabular}{cclcc}
\hline No & Mata Pelajaran & \multicolumn{1}{c}{ Pokok Bahasan } & Pelaksanaan ttp muka & Ket. \\
\hline 1 & IPA & - Pemeliharaan makhluk hidup & $2 \mathrm{x}$ ttp muka & \multirow{2}{*}{$3 \mathrm{jam} /$ minggu } \\
& IPA & - Tumbuhan & $5 \mathrm{x}$ ttp muka & \\
\hline
\end{tabular}

Tabel 2. Pelaksanaan Pembelajaran IPA

\begin{tabular}{ccccc}
\hline No & Mata Pelajaran & Pokok Bahasan & Pelaksanaan ttp muka & Ket. \\
\hline 1 & IPA & - Tanah & $7 \times$ ttp muka & 3 jam/ minggu \\
\hline
\end{tabular}

Alat evaluasi yang telah dipersiapkan praktisi adalah, butir tes formatif, membuat PR, format bimbingan. Alat evaluasi yang belum dibuat adalah penilaian proses. Untuk melengkapi itu praktisi bersama peneliti secara kolabotatif merancang bentuk alat evaluasi untuk penilaian proses.

b) Pelaksanaan dan Observasi Siklus 1

Pelaksanaan penilaian yang dilakukan oleh kedua praktisi dapat dijelaskan sebagai berikut:

1) Penilaian proses

Penilaian proses dilaksanakan oleh kedua praktisi selama pembelajaran berlangsung sesuai dengan tema/pokok bahasan-nya. Bentuk alat evaluasi yang dipergunakan adalah ceklis. Praktisi hanya berpedoman pada apa yang telah dibuat yaitu penilaian yang hanya mengarah pada aspek tingkah laku, sedangkan aspek penalaran/pengetahuan belum dilaksanakan.

2) Tugas membuat $P R$

Tugas membuat PR ini dalam asesmen merupakan bagian dari bentuk portofolio. Setiap pokok bahasan praktisi memberikan tugas PR 2 (dua) kali. Dengan demikian praktisi dalam siklus 1 ini mengumpulkan nilai PR sebanyak 4 kali yang kemudian dicari rataratanya.

3) Wawancara dan Diskusi

Dalam proses belajar mengajar, wawancara dan diskusi sudah dilakukan oleh praktisi, namun hasil wawancara dan diskusi ini tidak diinventarisir oleh praktisi.

4) Tes Formatif

Tes formatif dilaksanakan praktisi sesuai dengan jadwal yang telah ditentukan yaitu sebagai pelaksanaan ulangan harian. Tes 


\section{Jurnal Riset Pendidikan Dasar, 01 (1), April 2018 (18-24) Mansur S}

formatif dilaksanakan setelah berakhirnya pemberian satu pokok bahasan.

c) Refleksi Siklus 1

Jenis asesmen yang telah dilaksanakan oleh praktisi adalah: (1) Penilaian Proses (penilaian pengamatan), (2) Portofolio (pemberian tugas mengerjakan PR), (3) Wawancara dan Diskusi, dan (4) Tes Formatif (ulangan harian).

Dari asesmen yang dilakukan praktisi, data/hasil wawancara dan diskusi belum diinventarisasi. Demikian pula saat pelaksanaan penilaian proses, praktisi hanya mengamati unsur tingkah laku siswa saat berlangsungnya pembelajaran, sedangkan unsur penalaran/pengetahuan yang berkembang pada diri siswa belum teramati.

Berdasarkan masukan yang diterima dari praktisi, sebenarnya apa yang telah dirancang dalam pelaksanaan evaluasi telah dilaksanakan, seperti pada penilaian proses telah dilaksanakan penilaian dari aspek tingkah laku dan penalaran/pengetahuan siswa. Praktisi telah mengetahui siswa mana yang meningkat pengetahuannya yang mengalami kemajuan dalam proses belajar mengajar, siswa mana yang masih memerlukan bimbingan, dan siswa mana yang belum meningkat penalarannya. Karena tidak ada bukti administrasi secara tertulis bahwa guru telah melaksanakan penilaian itu, maka guru tidak dapat membuktikan bahwa mereka telah melaksanakan penilaian yang dimaksud.

Berdasarkan analisis data dengan menggunakan lembar obser-vasi, persentase yang telah diperoleh dari pelaksanakaan asesmen tersebut baru mencapai $60 \%$. Sesuai dengan kriteria keberhasilan bahwa pelaksanaan asesmen dalam pembelajaran IPA dikatakan berhasil jika pelaksanaan pembelajaran itu minimal telah mencapai $70 \%$ $84 \%$ yang berarti "Baik", maka pelaksanaan pemberian tindakan dilanjutkan pada siklus 2 .

2. Siklus 2

a. Perencanaan Siklus 2

Rancangan program pengajaran yang telah dibuat untuk cawu 1 tahun pelajaran
$2001 / 2002$, diperoleh perencanaan tatap muka mengajar disajikan pada tabel 2 .

Dari sejumlah pertemuan/tatap muka tersebut di atas, pelaksanaan asesmen direncanakan untuk mata pelajaran IPA penilaian proses, pemberian PR tiga kali sesuai dengan sub pokok bahasannya, dan pemberian formatif dilaksanakan sekali.

b. Pelaksanaan dan Observasi Siklus 2

Penilaian yang dilaksanakan oleh praktisi adalah:

1) Penilaian Proses

Penilaian proses untuk IPA dilaksanakan 3 kali. Bentuk alat evaluasi yang dipergunakan adalah ceklis. Dalam pelaksanaan penilaian proses ini praktisi berpedoman pada apa yang telah dibuat yaitu penilaian yang mengarah pada aspek tingkah laku dan aspek penalaran/pengetahuan.

2) Tugas membuat $P R$

Setiap pokok bahasan praktisi memberikan tugas PR tiga kali untuk IPA.

3) Wawancara dan Diskusi

Dalam proses belajar-mengajar ini wawancara dan diskusi sudah dilaksanakan oleh praktisi. Hasil wawancara dan diskusi sudah diinventarisir oleh praktisi yang ditulis pada format lembar bimbingan.

4) Tes Formatif

Tes formatif dilaksanakan oleh kedua praktisi sesuai dengan jadwal yang telah ditentukan yaitu sebagai "Ulangan Harian". Tes formatif dilaksanakan setelah berakhirnya pemberian satu pokok bahasan.

c. Refleksi Siklus 2

Asesmen telah dilaksanakan oleh praktisi. Jenis asesmen yang telah dilaksanakan adalah: (1) Penilaian Proses (penilaian peng-amatan), (2) Portofolio (pemberian tugas mengerjakan PR), (3) Wawancara dan Diskusi, dan (4) Tes Formatif (ulangan harian)

Semua hasil pelaksanaan asesmen telah diinventarisir oleh praktisi yang mengajar IPA. Demikian pula bukti-bukti tertulis tentang hasil pelaksanaan asesmen sudah mereka miliki.

Berdasarkan analisis data dengan menggunakan lembar observasi, persentase

Copyright C2018, JRPD, ISSN 2615 - 1723 (Print), ISSN 2615 - 1766 (Online) 


\section{Jurnal Riset Pendidikan Dasar, 01 (1), April 2018 (49-55) Mansur S}

yang telah diperoleh dari pelaksanaan asesmen tersebut telah mencapai $100 \%$ untuk IPA. Sesuai kriteria keberhasilan bahwa pelaksanaan asesmen dalam pembelajaran IPA dikatakan berhasil jika pelaksanaan pembelajaran itu minimal telah mencapai $70 \%$ - $84 \%$ yang berarti "Baik", maka pelaksanaan asesmen telah berhasil dilaksanakan.

\section{SIMPULAN}

Asesmen adalah suatu kegiatan dalam proses belajar mengajar yang dirancang oleh guru untuk mengetahui perkembangan belajar siswa. Berdasarkan pelaksanaan asesmen dalam pengajaran dapat dipilah menjadi dua macam yaitu, pada saat proses belajar dan hasil belajar. Sasaran yang diasesmen saat proses belajar adalah tingkat efektivias kegiatan belajar dalam rangka pencapaian tujuan pengajaran. Sedangkan sasaran yang diasesmen pada akhir pembelajaran adalah tingkat penguasaan siswa terhadap apa yang dipelajari. Sasaran yang dituju adalah mengusahakan terjadinya per-kembangan (pertumbuhan) belajar siswa, baik pertumbuhan kognitif (pengetahuan), motorik (ketrampilan), maupun afektif (emosi, perilaku, rasa aman, kepedulian lingkungan, dan sebagainya). Untuk dapat melaksanakan asesmen tersebut guru harus dapat merancangnya sesuai dengan karakteristik materi pelajaran yang diberikan.

Dari penelitian ini diperoleh gambaran bahwa asesmen telah dilaksanakan oleh guru SD. Namun karena tidak dilengkapi dengan data administrasi, bukti pelaksanaan asesmen tersebut tidak ada. Hal ini tergambar dalam pelaksanaan Siklus I. Barulah dalam Siklus II kegiatan asesmen tersebut dilaksanakan secara baik atau sempurna.

Asesmen bertujuan untuk mengetahui apa yang sudah diperoleh siswa, apa yang menjadi masalah siswa dalam belajar dan bagaimana pola belajar siswa yang tepat. Oleh karena itu guru hendaknya menyiapkan seperangkat data administratif berupa lembar penalaran dan pengamatan yang telah dilakukan. Hasil asesmen ini dipergunakan oleh guru sebagai dasar penentuan tindakan guru dalam memilih kegiatan dalam proses belajar mengajar agar kemampuan siswa bisa berkembang secara maksimal. Untuk mencapai maksud ini guru hendaknya peka terhadap keperluan dan kebutuhan siswa, minat dan bakat siswa, maka kedekatan guru kepada siswa sebagai pendidik sangat diperlukan.

Asesmen bersifat formatif (sebagai usaha guru mencari dasar tindakan yang paling tepat untuk memaksimalkan pertumbuhan siswa) dan tidak terpisahkan bahkan menyatu dengan proses belajar mengajar. Untuk itu sangat diperlukan daya inovatif dan kritis serta kreatif terhadap model-model pembelajaran yang dapat merangsang motivasi siswa untuk belajar.

Asesmen menghasilkan gambaran kemampuan siswa yang sangat kompre-hensif. Untuk itu tindakan-tindakan preventif guru sangat membantu siswa meningkatkan prestasi. Oleh karena itu seorang guru hendaknya dapat menangkap tanda-tanda apakah siswa yang diamati mengerti, bingung atau tidak siap, dan lain sebagainya. Pandangan mata, gerakan tangan, gerakan tubuh, gerakan kaki dan lain sebagainya dapat memberikan tanda-tanda yang sangat informatif. Tanda-tanda ini bila diamati dapat memberikan informasi yang sangat penting tentang perkembangan belajar siswa, kesulitan belajar siswa, dan pola belajar siswa.

$$
\text { Copyright } \text { C2018, JRPD, ISSN } 2615 \text { - } 1723 \text { (Print), ISSN } 2615 \text { - } 1766 \text { (Online) }
$$




\section{DAFTAR PUSTAKA}

Anthony, R.J. dkk. (1991). Evaluating Literacy A Perspective for Change. Toronto, Canada: Irwin Publishing.

Depdikbud. (1994). Pedoman Pelaksanaan Penilaian di Sekolah Dasar.

IKIP Malang, (1996). Petunjuk Pelaksanaan Praktek Pengalaman Lapangan Keguruan Program Diploma II Pendidikan Guru Sekolah Dasar. Malang: IKIP Malang.

Iskandar, S.M. (1997). Pendidikan Ilmu Pengetahuan Alam. Depdikbud.

Latief, M.A. (1997). Assesment dalam Proses Belajar Mengajar di Sekolah Dasar. Makalah pada Seminar Pengajaran bahasa SD, PPS. IKIP Malang.

Miles, M.B. \& Huberman, A.M. (1992). Analisis Data Kualitatif. Terjemahan oleh Tjetjep Rohandi Rihidi. Jakarta: UI Press.

Moleong, L.J. (1994). Metodologi Penelitian Kualitatif. Bandung: Remaja Rosdakarya.

Rofi'uddin, A., \& Darmiyati, Z. (1999). Pendidikan Bahasa dan Sastra Indonesia Kelas Tinggi. Jakarta: Depdikbud.

Tantra, D.K. (1997). Penelitian Tindakan: Konsep Dasar dan Pelaksanaan. Singaraja: P3M STKIP Singaraja. 